\title{
Examining Mobile Technology in Higher Education: Handheld Devices In and Out of the Classroom
}

\author{
Julie Mueller (Corresponding author) \\ Faculty of Education, Wilfrid Laurier University \\ 75 University Avenue West, Waterloo, ON N2L 3C5, Canada \\ Tel: 1-519-884-1970Ｅ-mail: jmueller@wlu.ca \\ Eileen Wood \\ Department of Psychology, Wilfrid Laurier University \\ 75 University Avenue West, Waterloo, ON N2L 3C5, Canada \\ Domenica De Pasquale \\ Department of Psychology, Wilfrid Laurier University \\ 75 University Avenue West, Waterloo, ON N2L 3C5, Canada \\ Ruth Cruikshank \\ School of Business and Economics, Wilfrid Laurier University \\ 75 University Avenue West, Waterloo, ON N2L 3C5, Canada
}

Received: June 8, 2012

doi:10.5430/ijhe.v1n2p43
Accepted: June 29, 2012

Online Published: July 5, 2012

The research is funded by Social Sciences and Humanities Research Council of Canada Standard Research Grant.

\begin{abstract}
This study followed an innovative introduction of mobile technology (i.e., BlackBerry ${ }^{\circledR}$ devices) to a graduate level business program and documented students' use of the technology from the time students received the devices to the end of their first term of study. Students found the BlackBerry ${ }^{\circledR}$ device easy to use, and were optimistic regarding its potential role as an instructional tool. Students were self-directed in their use of the devices and found ways to use them within and outside of their classroom even when specific uses were not provided by instructors. Students used their devices most frequently for communication purposes outside the classroom through applications such as BlackBerry Messenger. Overall, although supporting a modest positive view toward this initial introduction to mobile technology as a learning tool, classroom instructional use was more limited than student-directed use in and outside the classroom. A comprehensive examination of the instructional pedagogy that best supports the potential of mobile technology as a self-directed learning tool is necessary to address the limitations seen in this implementation.
\end{abstract}

Keywords: Mobile technology, Higher education, Self-regulated learning, Smart phones

\section{Introduction}

Mobile technologies, especially very portable handheld devices, are pervasive in business and social contexts in today's society and are starting to be considered in educational contexts. Worldwide use of information and communication technologies (ICTs) including cell phones, smart phones and other personal digital assistant devices (PDAs) continues to burgeon. For example, cell phones had already hit a saturation rate of $67 \%$ by 2009 , representing one of the most prevalent ICTs in the world (United Nations, 2010). The functions available through ICTs have also increased dramatically from simple call-only functions, when they were initially introduced, to current functions which include texting, emailing, Internet access, multimedia services and the ability to download 
applications to personalize the use of the device to the needs of the individual user (Lefebvre, 2009; Woodcock, Middleton, \& Nortcliffe, 2012). Given the popularity, affordability, portability and flexibility of such devices it is not surprising that educators have considered harnessing these devices within and beyond the classroom (Crippen \& Brooks, 2000; Liu, 2007; Motiwalla, 2007; Sharples, Arnedillo-Sánchez, Milrad, \& Vavoula, 2009; Sharples, Taylor, $\&$ Vavoula, 2007). The present study examines the introduction of the BlackBerry ${ }^{\circledR}$ device as a new teaching and learning tool for adult learners in a higher education learning environment.

In part, the desire to incorporate new technologies as part of instructional practice has been brought about by observations which support their ability to motivate students, encourage persistence on challenging tasks, and personalization of the learning environment (Gee, 2009; Hartnell-Young, 2009; Looi et al., 2009; Specht, 2010; Specht, Howell, \& Young, 2007). Concomitant with these observations about the potential of computers is educational reform which has seen a shift from viewing learners as passive receptors of information to a view that understands learners as self-regulated, active participants in the construction of knowledge (Abrami, 2001; Perry, 2002; Scott, Cole, \& Engel, 1992; Staub \& Stern, 2002; Vygotsky, 1978). Mobile technology has the potential to support and encourage the view of the student as a "self-regulated learner" and constructivist approaches to pedagogy both within and beyond the classroom by assisting the learner to interact with his/her environment, make independent choices and regulate their own learning (Bishuzen, 2008; Perry \& VandeKamp, 2001). In addition, the personal, multimodal, independent capabilities of devices such as the BlackBerry ${ }^{\circledR}$ and the iPod, offer the potential for "anywhere, anytime", creative, collaborative construction of knowledge (Chen \& Kinshuk, 2005; Evans \& Johri, 2008; Hoppe, Joiner, Milrad, \& Sharples, 2003; Norris \& Soloway, 2008).

However, along with the potential promise of mobile technology as an educational tool, there are concerns regarding the practicality of such devices for sustainability in educational environments. For example, evaluation of mobile technology use has identified difficulties including slow transmission of data, small screen and keyboard, and limited functionality in comparison to desktop systems (Chen \& Kinshuk, 2005). In addition, there are concerns that functions available through mobile technologies might inhibit or be detrimental for learning. For example, recent research reported learning decrements when students engaged in multi-tasking with online social networking, messaging or other communication platforms when also trying to complete school work activities (Junco \& Cotton, 2011; Wood, Zivcakova, Gentile, Archer, De Pasquale, \& Nosko, 2011) and younger students demonstrated decreased persistence in engaged observation following use of PDAs (Lai, Yang, Chen, Ho, \& Chan, 2007). A key challenge to designing mobile learning contexts is the potential for distraction and a possible "mismatch" between the disruptive nature of personal devices and existing learning contexts (Sharples, Arnedillo-Sánchez, Milrad, \& Vavoula, 2009).

The current study extends these early findings by helping us to understand how adult learners use mobile technologies in a 'real-world' learning context and this will inform us as to how and when this mobile technology can be used in the classroom.

\subsection{Learning Using Mobile Technologies}

The potential of mobile technology for encouraging "self-regulated learning" and supporting constructivist pedagogy can only be realized if the technology is used in a manner that matches these theoretical frameworks. Patten, Sánchez, and Tangney (2006) present a framework based on type of use to categorize the pedagogical approaches used with mobile technology in relation to constructivist pedagogy and "self-regulated learning". They concluded that the most appropriate uses of mobile technology are in the "synthesis of technology and pedagogical underpinnings" based on collaborative, contextual, and constructivist learning principles. For example, data collection can be done in locations outside the classroom and analysis can be done on the spot for immediate feedback. Reflective social practice is encouraged by the potential to store data for review and reflection and to share with an audience. In addition, collaborative features facilitate multi-learner collaboration and sharing knowledge outside the confines of the classroom. The instant access to information promotes both referential and reflective activities (Clough, Jones, Mcandrew \& Scanlon, 2008).

Overall, mobile technology has enormous potential to be used as a cognitive tool to support these characteristics (Lai et al., 2007; LaJoie, 2005; Motiwalla, 2007; Patten, Sanchez, \& Tangney, 2006), however, the potential benefits are closely connected to how it is actually used and the type of learning and activity it supports. The present study incorporates measures which address the impact of introducing mobile technology on students' motivation to use the technology for learning as well as non-learning activities, their satisfaction with its use as a teaching/learning tool and begins to explore how they used the devices as a learning tool. 


\subsection{Importance, originality, contribution to knowledge and relation to past research}

The ever-changing and increased presence of technology in education, demands that we continue to examine current technology's impact on learning and instruction. The Horizon Report lists one of the top ten "meta-trends" in technology as "People expect to work, learn, socialize, and play whenever and wherever they want to" (NMC, 2012). Mobile technology makes learning across time and contexts possible (Sharples et al, 2009). Past research has identified barriers and supports to integrating computer technology (e.g., Wood, Mueller, Willoughby, Specht, \& DeYoung, 2005) and more recent studies have begun to explore how digital technologies support learning and how these technologies impact on learners within and beyond the classroom context (e.g., Lai et al., 2007; Savage, Abrami, Hipps, \& Deault, 2009). Although this new research is beginning to provide answers regarding the impact of technology on learning and instruction, many questions are yet unanswered. Although the potential of mobile technology can be identified by examining its features, such as the independent, personalized nature, the portability and instant access, as well as its ability to support experiential, collaborative learning, the particular role of mobile technologies in classrooms and in learning contexts outside the traditional classroom is one area requiring more intensive examination.

\section{3 "Real World" Learning}

An important consideration regarding the introduction of mobile technologies is that the technologies represent a pedagogically appropriate and "real" learning experience. Mobile technologies are certainly an appropriate and important tool for students involved in business as mobile technologies serve as a critical tool in the business world (Lefebvre 2009). The technology project referred to in this study was a direct attempt to prepare graduate students for the technology that is used in 'real world' business communities and was developed in partnership with local technology companies.

\subsection{Current Study}

This study followed an innovative introduction of mobile technology to a graduate level business program. In the year this study was conducted every student and every professor in the first year of the graduate business program received a BlackBerry ${ }^{\circledR}$ device with an unlimited data plan and optional voice plan to foster the introduction of this technology as an instructional and learning tool. Students were given an initial group session on the basics of the device and a dedicated technical support staff member was available for the first several weeks of the program. The present study documented students' use of the technology from the week before students received the BlackBerry ${ }^{\circledR}$ devices to the end of their first term of study. Surveys were given to the students using the mobile device throughout the first 4 months that students used the BlackBerry ${ }^{\circledR}$ devices as a learning tool. These surveys provided "snapshots" regarding students' experiences and attitudes towards the devices when used in this context. This series of "snapshots" provides a more robust understanding of the use of the device than would a single, summative survey. The study presents an investigation of the authentic use of the BlackBerry ${ }^{\circledR}$ as a learning tool from the perspective of the students as learners.

\section{Method}

\subsection{Participants}

In total, 74 participants (39 males, $M_{\text {age }}=27.64, S D=6.14 ; 27$ females, $M_{\text {age }}=24.54, S D=4.31$; and 8 participants did not identify gender) from a total of 108 graduate business program students attending one university in a mid-sized Canadian city took part. Participants self-identified race/ethnic origin with $44.6 \%$ identifying themselves as Caucasian, $17.6 \%$ as East Asian, $10.8 \%$ as Asian, $2.7 \%$ as African, $2.7 \%$ as Other, $1.4 \%$ as European and $20.3 \%$ did not identify their ethnicity. The vast majority of the sample $(89.2 \%)$ were unemployed or on leave while completing their graduate business degree. Among the remaining students, $1.4 \%$ was employed full-time and $9.5 \%$ worked part-time. Participants' experiences in the business workforce ranged from 0 to 36 years $(M=4.37, S D=$ 6.03). Participants reflected the full spectrum of specializations within the graduate business program.

\subsection{BlackBerry ${ }^{\circledR}$ Initiative}

The decision to integrate this technology was initiated by the School of Business and Economics with the aim of preparing graduates for a mobile work environment as well as providing access to multi-media learning and collaborative communication.

Each student and each instructor who taught the graduate students in the Masters of Business Administration program at a major Canadian university was provided with a BlackBerry ${ }^{\circledR}$ Curve ${ }^{\mathrm{TM}}$ Model 8900 and an unlimited data plan. The devices included applications such as the BlackBerry Messenger, calendar, email, browser, documents 
to go, etc. Additional third party applications, such as Chalk Mobile, Desire2Learn 2Go, and Bloomberg Mobile, were also downloaded to the devices to encourage academic use both in and out of the classroom. Students were also allowed to download additional applications at their discretion.

The devices were distributed to all students in a whole group setting during an orientation session before the Master's program began. Initial training was provided at that session by university technical support and students took part in several introductory activities to familiarize themselves with basic functions on the device (e.g., camera, email, learning management system). Following the initial training session, a dedicated technical support staff member was available for questions and individual instruction and this person remained available for several weeks.

Individual faculty members were responsible for integrating the device in their own courses although the project was an agenda item at faculty meetings where the purpose and use of the devices were discussed as a group. Small group training for faculty was provided for the specific Learning Management Applications-Chalk and Desire2Learn 2 Go.

\subsection{Materials and Procedure}

In total, participants completed four short surveys. Two paper and pencil surveys were completed in large group settings in the classroom with one completed immediately prior to the distribution of mobile devices and one at the end of the four month first term. The length of the pre and post surveys necessitated a hard copy approach rather than completion using the BlackBerry ${ }^{\circledR}$ devices. Two additional surveys were "pushed out" to each student through the BlackBerry ${ }^{\circledR}$ device during the term approximately, one month apart, using Chalk Mobile, a Learning Management System App available on the mobile devices.

\subsubsection{Paper and Pencil Surveys}

The primary purpose of the first survey was to gain an understanding of the participants and their prior experiences with digital technologies. Demographic information (i.e., age, gender, ethnicity, and work experience), technology experience, perceived skill level with technology, and predicted use of the BlackBerry ${ }^{\circledR}$ were included.

Technology Experience was assessed by asking participants to indicate how many years experience they had with 6 technologies (i.e., computers, laptops, Internet, cell phone (with and without texting), and the BlackBerry ${ }^{\circledR}$ specifically). Perceived skill level with technologies was assessed through one, 4-part, question which asked participants to rate their skill with digital technologies relative to 4 groups of others (peers, work colleagues, general population under 25 years old, and general population over 25 years old), using a 5-point Likert-type scale (with anchors of $1=$ much less skilled and $5=$ much more skilled). Predicted use of the BlackBerry ${ }^{\circledR}$ device was assessed through one open-ended measure where participants were asked to estimate how many hours per week they expected to use their BlackBerry ${ }^{\circledR}$ device for learning in their business program.

The main function of the last paper-and-pencil survey was to gain knowledge regarding participants' experiences using the BlackBerry ${ }^{\circledR}$. This survey was comprised of 12 questions. Two of the 12 questions employed a 7-point Likert-type scale to assess students' perceptions of the usefulness of the BlackBerry ${ }^{\circledR}$ as a learning tool (choices ranged from 1 not at all to 7 very); one question considering the positive aspects regarding the BlackBerry ${ }^{\circledR}$ as a learning tool and one question considering the negative aspects. Specifically, the questions asked "Considering only the positive things about using the BlackBerry ${ }^{\circledR}$ for learning purposes, and ignoring the negative things, how positive are those things?" and "Considering only the negative things about using the BlackBerry ${ }^{\circledR}$ for learning purposes, and ignoring the positive things, how negative are those things?"

Skill with the BlackBerry ${ }^{\circledR}$ was assessed using one four-part question ("Which do you think best describes your skill with BlackBerry ${ }^{\circledR}$ technologies?") where participants compared themselves relative to 4 other groups (peers, work colleagues, general population under 25 years old, and general population over 25 years old), using a 5-point Likert-type scale (1= "much less skilled" to 5 = "much more skilled").

Use of the BlackBerry ${ }^{\circledR}$ device in the classroom was assessed through one open-ended question where students estimated how many hours per week they used their BlackBerry ${ }^{\circledR}$ device to support learning tasks related to the MBA courses during the term. Also students identified the relative use of the BlackBerry ${ }^{\circledR}$ for personal use and work/school use. Participants responded using a 5-point Likert-type scale where predominantly personal use was one anchor and predominantly school/work use was the other anchor.

Ease of use was assessed through one measure using a 5 point Likert-type scale (e.g., $1=$ very ill at ease to $5=$ very at ease).

Usefulness of the BlackBerry ${ }^{\circledR}$ for learning was assessed through three questions. One question asked "How useful 
was the BlackBerry ${ }^{\circledR}$ for supporting learning" $(1=$ not at all useful and $5=$ very useful $)$ and another open-ended question asked what was the most useful application for them and how they used that application. The final question asked students to rate six technologies with respect to how frequently they used each technology for school related tasks ranging from $1=$ never to $5=$ hourly.

\subsection{1 "Push Out" Surveys}

The first online survey asked participants five questions related to their BlackBerry ${ }^{\circledR}$ device use. Four questions used a 5-point Likert-type scale to rate participants' frequency of use and attitudes: How often do you use your BlackBerry ${ }^{\circledR}$ in your classrooms? (anchors of $1=$ never to $5=$ very often); How often do you use your BlackBerry ${ }^{\circledR}$ outside of your classroom? (anchors of $1=$ never to $5=$ very often); How easy do you find your BlackBerry ${ }^{\circledR}$ to use? (anchors of $1=$ very difficult to $5=$ very easy); How would you rate the BlackBerry ${ }^{\mathbb{B}}$ as a learning tool? (anchors of $1=$ not at all effective to $5=$ very effective). The fifth question asked participants to indicate, in an open-ended response, which application on your BlackBerry do you use most often?

The second online survey asked participants to answer four questions about their use of the mobile technology for learning. The first three questions employed a 5-point Likert-type scale to assess frequency of use of the BlackBerry ${ }^{\circledR}$ device: How frequently do you use your BlackBerry ${ }^{\circledR}$ in class for instructor-led activities? (anchors of $1=$ never to $5=$ several times a class); How frequently do you use your BlackBerry ${ }^{\circledR}$ in class for your own learning activities? (anchors of $1=$ never to $5=$ several times a class ); How frequently do you use your BlackBerry ${ }^{\circledR}$ in class for activities unrelated to class (e.g., social networking)? (anchors of $1=$ never to $5=$ several times a class). The final question was open-ended for participants to identify what application on their BlackBerry ${ }^{\circledR}$ they found to be the most useful in terms of their own academic learning.

\section{Results and Discussion}

Eight issues related to student attitudes and use of the BlackBerry ${ }^{\circledR}$ device in and out of the classroom were analyzed. First, it was important to determine technology experience within the sample, followed by an examination of students' perceived use of the BlackBerry and ease with the device. A series of analyses explored how the BlackBerry ${ }^{\circledR}$ device was perceived as a learning tool and how students used the device in and out of the classroom context, as well as the impact of the mobile technology on off-task behaviour and in comparison to other technologies.

\subsection{Technology Experience}

At the outset it was important to determine the participants' perceived level of skill with technology in general, and with the BlackBerry ${ }^{\circledR}$ devices in particular. Students indicated their number of years experience with seven specific technologies. Overall, the sample had a considerable number of years of experience with desktop computers $(M=$ $13.89, S D=4.85$ years $)$, the Internet $(M=10.95, S D=3.01$ years $)$, cell phones $(M=8.05, S D=3.51 ; M=5.44, S D=$ 3.23 years with and without texting, respectively) and laptops $(M=6.80, S D=3.81$ years). However, participants reported limited experience with BlackBerry ${ }^{\circledR}$ devices in particular $(M=1.03, S D=1.82$ years). Indeed, more than half of the participants (59.5\%) reported no prior experience with a BlackBerry ${ }^{\circledR}$ device prior to the study.

Participants were asked to rate their skill with digital technologies relative to peers, colleagues, younger members of the population ( 25 and under) and older members of the population ( 25 and over; see Table 1 for means). A repeated measures ANOVA was conducted to compare mean ratings for each group of "others". The significant main effect, $F_{(1,71)}=14.07, p<.001$, was followed up using t-tests which indicated that all groups significantly differed from one another. Specifically, the participants perceived themselves as slightly less skilled when compared to younger populations $(M=2.86, S D=1.04)$ and increasingly more skilled when compared to peers $(M=3.22, S D=.91)$, work colleagues $(M=3.64, S D=.91)$ and the general population over 25 years of age $(M=3.94, S D=.84)$, smallest $t_{(71)}=$ $2.75, p<.008$.

In summary, the participants indicated considerable experience with a range of digital technologies and perceived themselves to be quite skilled compared to most members of the population except groups younger than 25 years of age. In addition, it was clear that the BlackBerry ${ }^{\circledR}$ technology being introduced would be a novel technology for the majority of the participants.

\subsection{Uses of the BlackBerry ${ }^{\circledR}$ Device}

At the outset of the study participants predicted that they would use the BlackBerry for approximately 13 hours per week ( $M=12.78, S D=11.88$ hours) for learning purposes, however, by the completion of the study participants indicated that their actual use was only about half of their predicted use $(M=6.56, S D=7.19$ hours per week $), t_{(68)}=$ $3.93, p<.001$. 
Participants' use of technology across different contexts, school/work versus personal use contexts, was also assessed at the outset and the conclusion of the study. Initial use was considered to be approximately equal for all the contexts $(M=2.73, S D=.963)$. At the completion of the study students reported a little more work and school use $(M=3.44$, $S D=1.34)$, indicating a slight shift in use by the end of the intervention, $t_{(63)}=-3.90, p<.001$. The self-report of frequency of use does not provide details of the types of use but allows participants to define what they saw as school/work versus personal use of the device.

Together these outcomes suggest that students were very excited and optimistic that the BlackBerry ${ }^{\circledR}$ devices would serve as a highly integrated, regular part of their instructional programming but clearly the technology was utilized less frequently than expected. This outcome is consistent with numerous studies which report that despite widespread access and possible learning advantages (e.g., Blok, Oostdam, Otter, \& Overmaat, 2002; Mayer, Mautone, \& Protehro, 2002), computer technology remains under-utilized in education and the potential of computer technology is not being realized (Abrami, 2001; Mueller, 2009; Muir-Herzig, 2004). A recent meta-analysis of technology's impact on student achievement in higher education (Schmid, et al,., 2009) suggests that although technology has demonstrated medium positive effect sizes on learning outcomes, highest levels of technology saturation were related with negative effects. There are clearly additional variables beyond access and use that impact learning outcomes with technology that need to be addressed. Although it is beyond the scope of the present study, perceptions from the instructors regarding the pedagogical relevance of the BlackBerry ${ }^{\mathbb{B}}$ devices for learning might be key in understanding the relatively limited use of the BlackBerry ${ }^{\circledR}$ devices. For example, one consideration in the present study is that much of the in-class work in the business program involved face-to-face group activities. Given this context, the pedagogical merits of online social connectivity may have been irrelevant for the learning context of this program. Further exploration of instructor's pedagogical decisions regarding the use of mobile technologies is warranted in future research.

It is important that there was a shift in the use of the BlackBerry ${ }^{\circledR}$ even over this single term of use as students started to see it more as a tool for learning tasks than non-learning tasks. Clearly, over time, students can begin to see the tool as an instructional one and to orient the tool toward achieving instructional goals.

\subsection{Ease of Use with the BlackBerry ${ }^{\circledR}$ Device}

Extant research has consistently demonstrated a strong association between ease or comfort in using technology and greater use of technology (e.g., Mueller, Wood, Willoughby, Ross, \& Specht,, 2008; Sandholtz, Ringstaff, \& Dwyer, 1997; Wood et al., 2005). Ease of use was assessed at two points: on the first "push out" survey and at the end of term. Results for the "push out" survey indicated that most students were comfortable using the technology with $37.5 \%$ rating the device as 'somewhat easy' to use and an additional 35.7\% indicating it was 'very easy' to use. The mean rating supported that the device was easy to use $(M=4.13)$. This evaluation was consistent with ratings provided at the end of term where participants' perception of the BlackBerry ${ }^{\circledR}$ devices' ease of use was consistent with a rating of "very much at ease" $(M=4.53, S D=.839)$.

At the end of the term participants also were asked to evaluate their level of skill with the BlackBerry ${ }^{\circledR}$ device relative to peers, colleagues, younger members of the population and older members of the population. Skills equal to these groups would be represented with a mean of 3. In comparison to all groups, the participants rated themselves as slightly more skilled. A repeated measures ANOVA yielded a significant main effect supporting differences in the mean scores for each of these comparison groups, $F_{(1,72)}=16.69, p<.001$. Post hoc t-tests indicated that participants' perceptions about their skills did not differ for peers $(M=3.40, S D=.86)$, colleagues $(M=3.42, S D=.87)$ or younger members of the population ( 25 and younger; $M=3.29, S D=.92$ ) but perceived competence was much greater when comparing skills to an older population ( 25 and older; $M=3.88, S D=.82$ ) relative to any other group, smallest $t_{(72)}=4.63, \mathrm{p}<.001$.

In summary, participants indicated that they found the device easy to use and were comfortable that they were skilled users of the BlackBerry ${ }^{\circledR}$ device.

\subsection{Evaluating the Device as a Learning Tool}

Participants' global assessment of the value of the mobile device as a learning tool was just less than somewhat effective $(M=2.87)$ when assessed in the first "push out" survey. At the end of term participants were again asked to evaluate how useful the BlackBerry ${ }^{\circledR}$ was for supporting learning. Participants' ratings were only slightly above neutral $(M=3.67, S D=1.07)$. These middling ratings were further confirmed through two questions that teased apart the positive and negative feelings about the BlackBerry ${ }^{\circledR}$ as a learning tool. When participants were asked to consider only the positive aspects of using the BlackBerry ${ }^{\circledR}$ as a learning tool, participants viewed the BlackBerry ${ }^{\circledR}$ as slightly 
more than somewhat positive $(M=5.27, S D=1.51)$. When asked to consider only the negative aspects of using the BlackBerry $^{\circledR}$ as a learning tool, participants reported the BlackBerry ${ }^{\circledR}$ as neutral $(M=3.96, S D=1.65), t_{(73)}=4.51, p$ $<.001$ suggesting that participants felt slightly more positive about the BlackBerry ${ }^{\circledR}$ device for learning purposes than negative. Overall, these collective ratings throughout the study suggest a small positive advantage perceived for the BlackBerry ${ }^{\circledR}$ as a learning tool.

When asked to indicate, which application was the "most useful" as a "learning tool", on the first "push out" survey students identified four applications. The BlackBerry Messenger (43\%) and email (40\%) were most often identified and students indicated that these were useful for organizing groups and communicating to other students. The Internet was identified for browsing or searching $(7.4 \%)$ or as a reference tool $(4.4 \%)$. The third application involved the use of the Learning Management System (D2L and Chalk; 3\%) for classroom tasks. The final application identified as useful was Facebook (1.5\%). Interestingly, 5.9\% of the students who responded to this question indicated that they did not find any application useful. Similarly, in the second "push out" survey, again the majority of participants indicated that the most useful learning tools were the communication applications, namely, BlackBerry Messenger (26.7\%) and email (24.4\%) followed by the Internet for browsing and reading (20\%) and, finally, the Learning Management Systems (Chalk and D2L; 17.8\%). The proportion of students who found no application useful for learning purposes had risen to $11.1 \%$ by this second "push out" survey.

In the context of this self-report survey, participants were defining "learning purposes" according to their own perceptions. That is, they were identifying the differences between "learning" and "non-learning" individually. Students may not think of their mobile device as a core learning tool (Woodcock et al., 2012) but rather as an individual device that meets their particular needs. There was some variety in apps that were downloaded but those that were most frequently used were the ones traditionally thought of as "communication tools", e.g., BlackBerry Messenger.

In summary, as a learning tool, participants viewed the BlackBerry ${ }^{\circledR}$ in a marginally positive way, rating it as just somewhat effective and slightly more positively than negatively as an instructional tool. When participants used the BlackBerry $^{\circledR}$ to learn, clearly, communication for the intent of organizing or sharing information with other students served as the key learning advantage associated with the devices. It was also the case that a small proportion of students did not find the technology useful which may be indicative of their perceptions of limitations in how the technology was used in their classrooms (as is described below) or individual user characteristics. Teasing apart user and instructional variables would improve our understanding of where, when and for whom, these devices could be made most effective.

\subsection{Classroom use of the BlackBerry ${ }^{\circledR}$ Device}

In the first "push out" survey participants indicated using the mobile devices between sometimes and often $(M=3.43)$ in their classrooms. In the second "push out" survey participants were asked how frequently these in-class uses of the technology reflected instructor-led activities. The most frequent response was never with $50 \%$ of the students indicating that their in-class use was not teacher directed. An additional $36.8 \%$ of the participants indicated that their in-class use was teacher-led for some classes with a further 13.2\% indicating that teacher-led activities accounted for their classroom use in most classes. None of the students indicated that teacher led activities occurred several times a class.

Although teacher-led activities were not reported by half of the participants, self-directed learning using the BlackBerry ${ }^{\circledR}$ devices was a key tool for in-class learning. Specifically, when participants were asked how frequently they used their BlackBerry ${ }^{\circledR}$ in class for their own learning activities only $18.4 \%$ said never and an additional $8.9 \%$ said only once. Indeed, the vast majority of students reported using the mobile devices during class time to support their own learning for some classes $(60.5 \%)$ with the remaining students using it for most classes $(13.2 \%)$ or several times a class $(8.9 \%)$.

In summary, in-class use seemed to reflect more personal, self-directed learning than organized, teacher led activities in the present sample. The faculty in this project were unable to structure formal learning activities using the mobile technology due to timing of the implementation and the learning curve that existed in terms of changing pedagogy. Anecdotal comments outside the formal data collection of the project indicated that some faculty saw the potential benefits of the technology for learning purposes were limited and therefore not worth the time and cost. If students are to see mobile technology as an effective learning tool, instruction needs to support self-regulated, real-world tasks. Effective mobile learning examples from Sharples and colleagues (2009) show how learners use mobile devices to explore the physical environment, to support learning across contexts, and to encourage and evaluate conversations for 
learning. The mobile technology was used to record, make connections, maintain contact, and create multi-media products outside the traditional classroom.

\subsection{Off-task Behaviour}

Given the potential for the mobile devices to be a distraction during class time, it was important to assess the use of the devices for non-learning based activities. In the second "push out" survey participants were asked to identify how frequently they used their mobile devices for non-class related activities during class time. Overall, only $13.2 \%$ of the participants indicated that they never used their mobile devices for off-task behaviour during classes. Another $18.4 \%$ reported only using it once for off-task purposes. However, the remaining students ranged from using it in some classes (26.3\%), most classes (18.4\%), or several times per class (23.7\%) for non-class related activities during their class time. Clearly, students were using the BlackBerry ${ }^{\mathbb{B}}$ for off-task activities.

\subsection{Out of Class Use}

Mobile devices by definition can transport the learning context beyond the traditional classroom environment. In an effort to determine how often this tool was used outside of the classroom, external use was assessed in the first "push out" survey. All participants indicated that they did use the mobile devices outside of the classroom. Indeed, 21.4\% indicated that they used it often with an additional $60.7 \%$ indicating that they used it very often.

\subsection{Use of the BlackBerry ${ }^{\circledR}$ Relative to Other Technologies}

Students were asked to rate the frequency with which they used six different technologies for school-related tasks with one of these technologies being the BlackBerry ${ }^{\circledR}$. Cellphones and Smartphones were used slightly less often than weekly. The Internet, Computer, and BlackBerry ${ }^{\circledR}$ devices were all used often with scores slightly higher than daily and approaching hourly (See means Table 1). A repeated measures ANOVA indicated that differences in mean use across the technologies was significant, $F_{(1,67)}=49.28, p<.001$. Post hoc analyses indicated that Cellphone and Smartphone use did not differ. Similarly, use of the BlackBerry ${ }^{\circledR}$ and the Internet did not differ. Computer use was greater than all other devices, with BlackBerry ${ }^{\circledR}$ and Internet greater than Cellphone or Smartphone use. Previous research has identified the importance of understanding the relative importance of differing technologies (e.g., Chelsey, 2010). In the present study, students clearly integrated their BlackBerry ${ }^{\circledR}$ devices within their most frequently used technologies for learning. BlackBerry ${ }^{\circledR}$ use was frequent and served as an important technology outside the classroom for students by the end of this study.

\section{General Discussion}

Overall, the introduction of the BlackBerry ${ }^{\circledR}$ as a tool to support and encourage learning met with some successes and some limitations. At the outset it was clear that students found this to be a novel technology that was easy to use, and were optimistic regarding its potential role as an instructional tool. This optimism and perceived usefulness has been identified in other samples of students as well (Woodcock et al., 2012). Students were self-directed in their use of the BlackBerry ${ }^{\circledR}$ devices. Consistent with a self-regulated learner model, students found ways to use the BlackBerry ${ }^{\circledR}$ within and outside of their classroom even when specific uses were not provided by instructors. As might be expected for a mobile device, students used their BlackBerry ${ }^{\circledR}$ devices more frequently outside the classroom than in the classroom. These findings suggest that students found the devices to be useful for some learning activities, especially in contexts where other students were not readily available for interaction. Overall, the results, although supporting a modest positive view toward this mobile technology as a learning tool, were not overwhelming and the BlackBerry ${ }^{\circledR}$ devices were not used at a high level in the classroom. As mentioned earlier, the limitation of use was predominantly seen as coming from the instructors as students evolved ways to use the technology both beyond and within the classroom walls. The limited use may reflect pedagogical limitations as perceived by the instructors and lack of professional training and support around the implementation of mobile technology as a learning tool. The benefits of mobile technology as a learning tool are realized in authentic learning settings that give students "responsibility for designing and delivering a piece of work" (Woodcock et al., 2012, p. 11). Instructors take on the role of developer in an innovative approach to learning where mobile technology supports collaboration, communication, and creation.

The impact of the pedagogical beliefs of teachers on classroom practice has been well-documented (Brophy \& Good, 1986; Buchmann, 1987; Lumpe, Haney, \& Czerniak, 2000; Nespor, 1987; van Driel, Beijaard \& Verloop, 2001) but the direct influence on technology integration is not as clear (Wozney, Venkatesh, \& Abrami, 2006). In general, teachers are likely to use their past experiences, beliefs, and attitudes about learning and teaching to develop their beliefs about technology as a teaching method or instructional tool, depending on how they classify technology (Ertmer, 2005; McGrail, 2005). Their attitudes and beliefs about learning and teaching will influence how they think about technology. To use digital technology as a cognitive tool in knowledge construction, educators must 
acknowledge the technology as a learning tool and be able to incorporate it into the classroom. Educators ultimately determine whether and how technology will be used (Mercer \& Fischer, 1992). The survey data reported on in this paper does not include responses or reflection from the instructors as to why the mobile technology was or was not used in class, or what the supports and barriers to its implementation were. As indicated earlier, the introduction of the mobile technology was done very close to the beginning of the program and there was little time for instructors to learn about the technology and consider how it might be integrated within their courses. Certainly investigation of these factors and the perspective of the instructor will add to understanding of mobile technology as an instructional tool.

Students indicated that the tool was especially important for communication and organizing tasks, specifically in regards to group work. This outcome is consistent with a body of research that supports mobile technologies, especially those with messaging and calling options, as important tools for supporting relationships. Interestingly, this type of communication with mobile technologies is seen to promote "strong-tie" relationships rather than superficial relationships (Green, 2002; LeFebver, 2009). That is, communication serves to "keep close" those individuals that are needed for support. Although the BlackBerry ${ }^{\circledR}$ devices were introduced as a learning tool in the present study, they may also have offered an unintended social support system for students by allowing students to develop and sustain relationships beyond the in-class contact time. The social support provided through these technologies may be important for promoting engagement and retention in academic programs (e.g., Junco \& Cotten, 2011)

One concern that became apparent was the issue of off task behaviour. Off task behaviour, and multi-tasking with technologies in learning contexts can inhibit learning and distract the learner from the task at hand (Junco \& Cotton, 2011; Mayer \& Moreno, 2003; Wood et al., 2011). A majority of graduate students in this study did indicate that they used the mobile technology during class for tasks that were not related to learning. The off-task behaviour with the technology could be replacing off-task behaviour of another kind or making distractions more readily available. Much of the research that suggests positives outcomes from mobile technology, has examined e-learning or distance learning situations where the potential of mobile technology to connect across time and space is utilized, rather than in a face to face situation that existed for these graduate students (e.g., Chapel, 2008; Chen \& Kinshuk, 2005; Motiwalla, 2007; Wagner, 2008). The potential advantages of the BlackBerry ${ }^{\circledR}$ device may be less connected to in-class use and more directly related to the applications that participants listed as effective for learning, including collaboration and communication tools.

Previous research looking at the specific uses of mobile technology indicates that uses related to data collection, location awareness, and collaboration are particularly suited to handheld devices and present new learning opportunities that would not be possible without this emerging technology (Patten et al., 2006). It may be that if mobile technology is to augment present instruction, it needs to be implemented along with innovative, personalized, and collaborative approaches to instruction, both in and out of the classroom. The connectivity feature of the mobile technology was seen as a positive by many of the participants but was also mentioned as a drawback. A small percentage of students indicated that the constant connection was a drawback because the 24/7 availability provided them with no chance to step away from the learning. Recent research suggests that mobile technology can contribute to a feeling of being rushed during work but Bittman, Brown, \& Wajcman (2009) suggest that this same pressure is not associated with cell-phones outside of work rather mobile technology connectivity results in a stronger social connection. In the present study, it may be that with experience some learners adjusted how they used the BlackBerry across different contexts which provided a more balanced use of the technology in and out of the classroom. Other students however, may have required more time, experience or direction in how to manage the connectivity of the device. It was also interesting to note that a smaller group of participants indicated that they saw no useful application of the device as a learning tool. Clearly, explicit instruction and clear opportunities for practice are a necessary component for the introduction of new technologies in the instructional context if all learners are to be aware of how to use the technology for learning.

Sharples, Arnedillo-Sanchez, Milrad and Vavoula (2009) expand on the potential of mobile technology to posit that its essence takes learning outside the traditional classroom and allows the physical and conceptual movement necessary for learning to take place more readily. These authors suggest that the design of mobile learning should be "driven by specific learning objectives." The ability of current mobile devices, such as cell phones and PDAs, to be carried with individuals and used in a variety of settings at virtually anytime, provides the possibility to re-design learning. Sharples et al. (2009) suggest that "mobile learning" can be 'unpacked' to include mobility in several dimensions: physical space, technology (portable tools), conceptual space, social space, and learning dispersed across time. If mobile learning is defined more broadly than the use of a mobile device for learning, there will need to be change to pedagogy and structure of classrooms to see the full benefits of incorporating mobile devices such as 
the BlackBerry ${ }^{\circledR}$.

The introduction of mobile technology as a learning tool with this sample of graduate business students indicates that the technology is still a relatively novel instructional and learning tool and that it is used more frequently as a communication device amongst peers than as an instructional tool directed by faculty. Trends did emerge across the relatively short period of use that indicated students were beginning to use the mobile technology as a school/work tool and not only as a social media connector. Further examination from the instructor's perspective would answer remaining questions related to how mobile technology may impact instruction along with its apparent support for independent learning and communication.

\section{References}

Abrami, Philip C. (2001). Understanding and promoting complex learning using technology. Educational Research and Evaluation, 7(2-3), 113-136. http://dx.doi.org/10.1076/edre.7.2.113.3864

Beishuizen, J. (2008). Does a community of learners foster self-regulated learning? Technology, Pedagogy and Education, 17(3), 183-193. http://dx.doi.org/10.1080/14759390802383769

Bittman, M., Brown, J. \& Wajcman, J. (2009). The cell phone, constant connection and time scarcity in Australia. Social Indicators Research, 93, 229-233. http://dx.doi.org/10.1007/s11205-008-9367-8

Blok, H., Oostdam, R., Otter, M. E., \& Overmaat, M. (2002). Computer-assisted instruction in support of beginning reading instruction: A review. Review of Educational Research, 72(1), 101-130. http://dx.doi.org/10.3102/00346543072001101

Brophy, J. \& Good, T. L. (1986). Teacher Behavior and Student Achievement. In Handbook of Research on Teaching, $3^{\text {rd }}$ edition. Wittrock, New York: Macmillan, 328-375.

Buchmann, M. (1987). Role over person: Justifying teacher action and decisions. Scandinavian Journal of Educational Research, 31(1), 1-21. http://dx.doi.org/10.1080/0031383870310101

Chapel, E. (2008). Mobile technology: the foundation for an engaged and secure campus community. Journal of Computing in Higher Education, 20(2), 15-23.

Chen, J., \& Kinshuk. (2005). Mobile technology in educational services. Journal of Educational Multimedia and hypermedia, 14(1), $91-109$.

Chelsey, N. (2010). Technology use, and employee assessments of work effectiveness, workload and pace of life. Information, Communication \& Society, 13(4), 485-514.

Clough, G., Jones, A. C., Mcandrew, P., \& Scanlon, E. (2008). Informal learning with PDAs and smartphones. Journal of Computer Assisted Learning, 24(5), 359-371.

Crippen, K. J., \& Brooks, D. W. (2000). Using personal digital assistants in clinical supervision of student teachers. Journal of Science Education and Technology, 9(3), 207 - 211.

Ertmer, P. A. (2005). Teacher pedagogical beliefs: The final frontier in our quest for technology integration? Educational Technology Research and Development, 53(4), 25-39. http://dx.doi.org/10.1007/BF02504683

Evans, M. A., \& Johri, A. (2008). Facilitating guided participation through mobile technologies: Designing creative learning environments for self and others. Journal of Computing in Higher Education, 20(2), 92 - 105.

Gee, J. P. (2009). Digital media and learning as an emerging field, part I: How we got here. International Journal of Learning and Media, 1(2), 13-23.

Green, N. (2002). On the Move: technology, mobility, and the mediation of social time and space. The Information Society, 18(4), 281-292.

Hartnell-Young, E. (2009). The importance of teaching roles when introducing Personal Digital Assistants in a Year 6 classroom. Technology, Pedagogy, and Education, 18(3), 1, 3-17.

Hoppe, H. U., Joiner, R., Milrad, M., \& Sharples, M. (2003). Guest editorial: wireless and mobile technologies in education. Journal of Computer Assisted Learning, 19(3), 255 - 259.

Junco, R. \& Cotton, S. (2011). Perceived academic effects of instant messaging use. Computers \& Education, 56, 370-378. http://dx.doi.org/10.1016/j.compedu.2010.08.020

Lai, C., Yang, J., Chen, F., Ho, C., \& Chan, T. (2007). Affordances of mobile technologies for experiential learning: The interplay of technology and pedagogical practices. Journal of Computer Assisted Learning, 23(4), 326-337. 
LaJoie, S. P. (2005). Extending the scaffolding metaphor. Instructional Science, 33(5-6), 541-557. http://dx.doi.org/10.1007/s11251-005-1279-2

Lefebvre, C. (2009) Integrating cell phones and mobile technologies into public health practice: A social marketing perspective: Social marketing and health Communication. Health Promotion practice, 10(4), 490-494. http://dx.doi.org/10.1177/1524839909342849

Liu, T. C. (2007). Teaching in a wireless learning environment: A case study. Educational Technology \& Society, 10(1), 107-123.

Looi, C., Wong, L., So, H., Seow, P., Toh, Y., Chen, W., Zhang, B., Norris, C. \& Soloway, E. (2009). Anatomy of a mobilized lesson: Learning my way. Computers \& Education, 53(4), 1120-1132. http://dx.doi.org/10.1016/j.compedu.2009.05.021

Lumpe, A. T., Haney, J. J., \& Czerniak, C. M. (2000). Assessing teachers' beliefs about their science teaching context. $\begin{array}{lllll}\text { Journal of Research in } & \text { Science } & \text { Teaching, } & \text { 37(3), }\end{array}$ http://dx.doi.org/10.1002/(SICI)1098-2736(200003)37:3<275::AID-TEA4>3.0.CO;2-2

Mayer, R. E., Mautone, P., \& Prothero, W. (2002). Pictorial aids for learning by doing in a multimedia geology simulation game. Journal of Educational Psychology, 94(1), 171-185. http://dx.doi.org/10.1037/0022-0663.94.1.171

Mayer, R. \& Moreno, R. (2003). Nine ways to reduce cognitive load in multi media learning. Educational Psychologist, 38(1), 43-52.

McGrail, E. (2005). Teachers, technology, and change: English teachers' perspectives. Journal of Technology and Teacher Education, 13, 5-24.

Mercer, N., \& Fisher, E. (1992). How do teachers help childen to learn? an analysis of teachers' interventions in computer-based activities. Learning and Instruction, 2(4), 339-355. http://dx.doi.org/10.1016/0959-4752(92)90022-E Motiwalla, L. F. (2007). Mobile learning: A framework and evaluation. Computers \& Education, 49(3), 581-596.

Mueller, J. (2009). Computer integration in elementary and secondary schools: Variables influencing educators. Unpublished doctoral dissertation, Wilfrid Laurier University, Waterloo, Ontario.

Mueller, J, Wood, E., Willoughby, T., Ross, C., \& Specht, J. (2008). Identifying discriminating variables between teachers who fully integrate computers and teachers with limited integration. Computers \& Education, 51(4), 1523-1537. http://dx.doi.org/10.1016/j.compedu.2008.02.003

Muir-Herzig, R. G. (2004). Teachnology and its impactc in the classroom. Computers and Education, 42, 111-131.

Nespor, J. (1987). The role of beliefs in the practice of teaching. Journal of Curriculum Studies, 19(4), 317,328

NMC. (2012). A Communiqué from the Horizon Project Retreat. An NMC Horizon Project Publication. [Online] Available: http://www.nmc.org/pdf/2012- Horizon-Project-Retreat-Communique.pdf

Norris, C., \& Soloway, E. (2008). Handhelds: Getting mobile. District Administration, July 2008, [Online] Available: http://www.districtadministration.com/viewarticlepf.aspx?articleid=1638 on September 29, 2009.

Patten, B., Sanchez, I. A., \& Tangney, B. (2006). Designing collaborative, constructionist and contextual applications for handheld devices. Computers \& Education, 46, 294-308.

Perry, N. E. \& VandeKamp, K. O. (2000). Crating contexts that support young children's development of self-regulated learning. International Journal of Educational Research, 33, 821-843.

Perry, N. E., VandeKamp, K. O., Mercer, L. K., \& Nordby, C. J. (2002). Investigating teacher-student interactions that foster self-regulated learning. Educational Psychologist, 37(1), 5-15.

Sandholtz, J. H., Ringstaff, C., \& Dwyer, D. C. (1997). Teaching with technology: Creating student-centered classrooms. New York: Teachers College Press.

Savage, R. S., Abrami, P., Hipps, G., \& Deault, L. (2009). A randomized controlled trial study of the ABRACADABRA reading intervention program in grade 1. Journal of Educational Psychology, 101(3), 590-604.

Schmid, R. F., Bernard, R. M., Borokhovski, E., Tamim, R., Abrami, P. C., Wade, C. A., Surkas, M. A., \& Lowerison, G. (2009). Technology's effect on achievement in higher education: A stage I meta-analysis of classroom applications. Journal of Computing in Higher Education, 21(2), 95-109. http://dx.doi.org/10.1007/s12528-009-9021-8

Scott, T., Cole, M., \& Engel, M. (1992). Chapter 5: Computers and education: A cultural constructivist perspective. Review of Research in Education, 18(1), 191-251. http://dx.doi.org/10.3102/0091732X018001191 
Sharples, M., Arnedillo-Sánchez, I., Milrad, M., \& Vavoula, G. (2009). Mobile learning: small devices, big issues. In Balacheff, N., Ludvigsen, S., Jong, T., Lazonder, A. and Barnes, S. (eds) Technology-Enhanced Learning, Part IV, Springer Netherlands, pp. 233-249.

Sharples M., Taylor J. \& Vavoula G. (2007) A theory of learning for the mobile age. In The Sage Handbook of E-learning Research (Eds.) R. Andrews \& C. Haythornthwaite, Sage Publications, London, pp. 221-247.

Specht, J. A. (2010). Strategies for engaging students with learning disabilities. In C. Black (Ed.). Classroom Communication, 23-30. Madison, WI: Atwood Publishing.

Specht, J., Howell, G., \& Young, G. (2007). Students with special education needs and their use of assistive technology during transition to secondary school. Childhood Education, 83(6), 385-389.

Staub, F. C., \& Stern, E. (2002). The nature of teachers' pedagogical content beliefs matters for students' achievement gains: Quasi-experimental evidence from elementary mathematics. Journal of Educational Psychology, 94(2), 344-355. http://dx.doi.org/10.1037/0022-0663.94.2.344

United Nations (February 23 2010). Press Conference on International telecommunication Union's report: measuring the Information society 2010. Department of Public Information, News and media division, New York, New York. [Online] Available: www.un.org/News/briefings/docs/2010/100223_ITU.doc.htm.

van Driel, J. H., Beijaard, D., \& Verloop, N. (2001). Professional development and reform in science education: The role of teachers' practical knowledge. Journal of Research in Science Teaching, 38(2), 137-158. http://dx.doi.org/10.1002/1098-2736(200102)38:2<137::AID-TEA1001>3.0.CO;2-U

Vygotsky, L. (1978). Mind in society: The development of higher psychological processes. Cambridge, MA: Harvard University Press.

Wagner, E. D. (2005). Enabling mobile learning. EDUCAUSE Review, 40(3), 41-42, 44, 46-52.

Woodock, B. Middleton, A. \& Nortcliffe, A. (2012) Considering the smartphone learner: an investigation into student interest in the use of personal technology to enhance their learning. Student Engagement and Experience Journal, 1 (1), $1-15$.

Wood, E., Mueller, J., Willoughby, T., Specht, J., \& DeYoung, T. (2005). Teachers' perceptions: Barriers and supports to using technology in the classroom. Education, Communication, \& Information, 5, 183-206.

Wood, E., Zivcakova, L., Gentile, P., Archer, K., De Pasquale, D. \& Nosko, A. (2011). Examining the impact of off-task multi-tasking with technology on real-time classroom learning. Computers and Education, 58, 365-374.

Wozney, L., Venkatesh, V., \& Abrami, P. (2006). Implementing computer technologies: Teachers perceptions and practices. Journal of Technology and Teacher Education, 14(1), 173-207. [Online] Available: http://search.proquest.com/docview/62165493?accountid=15090; http://www.aace.org

Table 1. Frequency use of technologies for school related tasks

\begin{tabular}{llll}
\hline & Mean & Standard \\
& Deviations & $\mathrm{N}$ \\
\hline Computers & 4.60 & .55 & 68 \\
Cell phones (no texting) & 2.87 & 1.29 & 68 \\
Cell phones (texting) & 2.90 & 1.63 & 68 \\
Smartphone & 2.65 & 1.67 & 68 \\
BlackBerry & 4.09 & 1.00 & 68 \\
Internet & 4.31 & 1.00 & 68 \\
\hline
\end{tabular}

